\begin{tabular}{rr} 
çağdaş & Yaratıcı Drama Dergisi 2017, 12(1), 47-68 \\
drama & www.yader.org \\
\hline
\end{tabular}

\title{
Süreçsel Drama Oturumlarının Okul Öncesi Öğretmen Adaylarının Medya Okuryazarlığı Seviyelerine Etkisi*
}

\begin{tabular}{|c|c|c|}
\hline & & $\begin{array}{c}\text { Şule Alıcı }{ }^{1} \\
\text { Özlem Öznur Gökbulut }{ }^{2}\end{array}$ \\
\hline Makale B & & $\ddot{\mathbf{O} z}$ \\
\hline DOI: 10.216 & ler.2017.003 & Çalışma 3. ve. 4. sinıf okul öncesi öğretmen adaylarının medya \\
\hline Makale Geç & & eçsel drama yoluyla katki saglamak \\
\hline Geliş tarihi & 19.12.2016 & 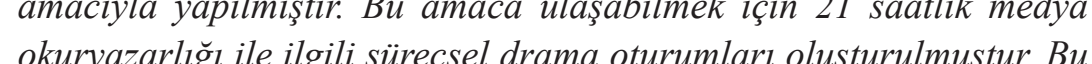 \\
\hline Dïzeltme & 07.05 .2017 & çalışma 15 kadın ve 1 erkek olmak üzere toplam 16 ögretmen adayl \\
\hline Кавй & 22.05 .2017 & ile yürütülmüştür. Araştırma boyunca veriler, katılımcı paylaşımları \\
\hline Anahtar Söz & & Iokumaniar olme \\
\hline Medya okury & & yöntemi kullanılarak yapılmıştır. Çalışma sonucunda süreçsel drama \\
\hline $\begin{array}{l}\text { Süreçsel dra } \\
\text { Ögretmen ac }\end{array}$ & & atölyelerinin katılımcıların medya okuryazarlı̆̆ı seviyeleri üzerinde \\
\hline Okulöncesi & & olumlu etkiler bıraktı̆̆ı görülmüştür. \\
\hline
\end{tabular}

\section{Impact of Pre-school Teacher Candidates on Media Literacy Levels of Proccessional Drama Sessions}

\begin{tabular}{|c|c|c|}
\hline \multicolumn{2}{|c|}{ Article Info } & Abstract \\
\hline \multicolumn{2}{|c|}{ DOI: $10.21612 /$ yader.2017.003 } & TThe aim of this study is to make a contribution to the media literacy \\
\hline \multicolumn{2}{|c|}{ Article History } & via process drama. To reach this aim, 21-hour process drama settings \\
\hline Received & 19.12.2016 & related to media literacy were constructed. This study were conducted \\
\hline Revised & 07.05 .2017 & with totally 16 pre-service teachers whom are 15 female and 1 male. \\
\hline Accepted & 22.05 .2017 & $\begin{array}{l}\text { Throughout this research, qualitative data including reflections and } \\
\text { documents were collected. In other words, in this study, qualitative }\end{array}$ \\
\hline \multicolumn{2}{|l|}{ Keywords } & research design was used. The collected data were analyzed via content \\
\hline \multicolumn{2}{|c|}{ Media literacy } & analysis. After completing this research, it was seen that process drama \\
\hline \multicolumn{2}{|c|}{ Process drama } & workshops had positive impact on participants' media literacy levels. \\
\hline
\end{tabular}

Early childhood education

* $\quad$ Bu çalışma, 31 Ağustos - 3 Eylül 2016 tarihleri arasında Dublin, İrlanda' da düzenlenen 26. EECERA Konferansı'nda “Investigation of process drama workshops' impact on teacher candidate's media literacy levels" adlı bildiri olarak sunulmuştur. Ayrıca MEB Özel Doğaç Yaratıcı Drama Liderliği/Eğitmenliği Kursu bitirme projesinden geliştirilerek yazılmıştır.

1 Arş. Gör. Orta Doğu Teknik Üniversitesi, E-posta: alicisule@gmail.com.

2 Bilim Uzmanı, Milli Eğitim Bakanlığı, E-posta: ooozlemgokbulut@gmail.com. 


\section{Giriş}

Medyanın 19. yüzyıldan bu yana kamusal söylem aracı olma rolünün güçlenmesi ve televizyonun keşfinden sonra sesin yanında görüntünün de yer alması ona aynı anda her yerde bulunabilme imkanı sağlayarak etkileşim alanını ve olumlu ya da olumsuz etkilerini daha da arttırmıştır. Buna ek olarak günümüzde medya gençlerin en önemli politik bilgi kaynağını oluşturmaktadır ve daha da önemlisi hepimiz çok önemli demokratik kararlarımızdan bazılarını medya kanıtlarına dayalı vermekteyiz (Altun, 2011).

Bütün bu gelişimlerin ve değişimlerin 1şı̆̆ında son yıllarda "çocuk ve medya" konusu da giderek güncel ve küresel bir konu haline gelmiştir. Özellikle okulöncesi dönem çocuklarının okuma yazma bilmemelerinden dolayı görsel medya, televizyon, bilgisayar ve dijital medyanın etkisi onlar üzerinde daha fazla olmaktadır. Çünkü çocuklar hareketli bir nesneye daha çok dikkat etmektedirler. Örneğin, televizyon bilhassa taklit yoluyla öğrenen çocuk için etkili bir öğretmen rolü üstlenmektedir. Okul öncesi dönemde çocuklar televizyon filmindeki kahramanlarla önemli bir özdeşim modeli oluştururlar. Bu dönemde çocuklar nesne ve olayları televizyonda görerek ve işiterek hareketli olarak tanımaktadırlar. Bu olumsuz etkilerinin yanı sıra medyanın çocuklar üzerinde "dünya görüşünü genişletme", "kalıp yargıları yıkma" ve "farklı fikirlere erişimi sağlama" gibi olumlu etkileri de bulunmaktadir (Yavuzer, 2013).

$\mathrm{Bu}$ durumda hem olumlu hem de olumsuz etkileri bulunan medyanın etkili ve bilinçli kullanımının önemi daha da artmakta ve bunları kapsayan medya okuryazarlığı kavramı ön plana çıkmaktadır. Bu noktada, medya okuryazarı bireyler yetiştirmek Birlemiş Milletler Eğitim, Bilim ve Kültür Kurumu (UNESCO)'nun bir amacı olarak ortaya çıkmış ve medya okuryazarlığını 1979 Paris birleşiminde şu şekilde tanımlanmıştır: "Hem kuramsal ve uygulamalı sanatlar olarak medyanın tüm seviyelerdeki (ilk, orta, lise, yetişkin eğitimi, yaşam boyu eğitim) ve tüm durumlardaki bütün çalışma, öğrenme ve öğretim biçimleri, tarihi, yaratıcıllğı, kullanımı ve değerlendirilmesi, hem de toplumda medyanın işgal ettiği yer, sosyal etkisi, medya iletişiminin, katılımının içinde saklı olan anlam, sebep oldukları algılama tarzı değişikliği, yaratıcı çalışma rolü ve medyaya ulaşma” (UNESCO, 1984, s. 8).

2002 y1lında İspanya'da UNESCO’ya üye ülkelerin bir araya gelerek medya okuryazarlığ çalışmalarını yenilemeleri sonucunda medya okuryazarlığı "Tüm iletişim medyasılyla ilgilenir ve herhangi bir teknoloji çeşidi ile iletilen hem yazılmış kelime, grafik, ses, fotoğraf hem de hareketli resmi içerir; insanların toplumlarında kullanılan iletişim medyasına ve bunların çalışma biçimlerine ilişkin bir anlayışa sahip olmalarını ve başkalarıyla iletişime geçmek için bu medyayı kullanma konusunda beceriler kazanmalarını sağlar" biçiminde ifade edilmiştir:

Medya, medium kelimesinin çoğulu olup Latincede ortam, araç anlamına gelmektedir. Türk Dil Kurumu sözlüğüne göre ise medya "iletişim ortamı" ya da "iletişim araçları" anlamına gelmektedir. Bunun yanı sıra medya yaygın olarak kitle iletişim araçları (gazete, dergi, radyo, televizyon ve internet) olarak da tanımlanmaktadır. Buradan da anlaşıldığı üzere kesin bir medya tanımı bulunmamaktadır. Medya, kitle iletişim araçları (kitap, dergi, televizyon v.b.) olanlar ve olmayanlar (cep telefonu, e-mail) olarak ayrılmış olsa bile bunlar arasında da kesin bir çizgiyle yapılmış ayrım yoktur (Livesey, 2011; Potter, 2013). 


\section{Medya Kavramı ve Uluslararası Alanda ve Türkiye'de Medya Okuryazarlığı}

2007 yılında UNESCO’nun aracılığıyla Paris'te tekrar bir araya gelen ülkeler, medyanın toplumdaki yeri ve gücünün son yıllarda daha çok arttığını ve artık her vatandaşın kullanılan sembolik sistem ne olursa olsun bilgiyi eleştirel olarak analiz etmeye, kendi içeriklerini kendileri üretmeye ve mesleki ve sosyal değişime kendilerini adapte etmeye bugün çok daha fazla ihtiyaç duydukları konusunda hemfikir olmuşlardır. Bu nedenle bu toplantı sonunda "Medya Eğitimi Tavsiye Kararları" (UNESCO, 2007) alınmıştır. Dört yol gösterici ilkeye dayalı olarak geliştirilen on iki tavsiye kararı şöyledir:

a) Tüm ĕgitim seviyelerinde kapsamlı medya ĕgitimi programlarının geliştirilmesi

Tavsiye Kararı 1: Kapsamlı bir medya eğitimi tanımını kabul etmek

Tavsiye Kararı 2: Medya eğitimi, kültürel çeşitlilik ve insan haklarına saygı arasındaki bağlantıları güçlendirmek

Tavsiye Kararı 3: Temel becerileri ve değerlendirme sistemlerini tanımlamak

b) Öğretmen ĕgitimi ve toplumsal alanda diğer paydaşların farkindalı̆̆ının arttirlması

Tavsiye Kararı 4: Medya ĕgitimini temel öğretmen ĕgitimi ile ilişkilendirmek

Tavsiye Kararı 5: Uygun pedagojik yöntemler geliştirmek

Tavsiye Kararı 6: Ĕgitim sistemi içindeki tüm paydaşları seferber etmek

Tavsiye Kararı 7: Toplumsal alandaki tüm paydaşları seferber etmek

Tavsiye Kararı 8: Medya eğitimini yaşam boyu öğrenme çerçevesinde ele almak

c) Araştırma ve bu araştırmaların dă̆ıtımı için iletişim ă̆

Tavsiye Kararı 9: Yüksek öğrenimde medya eğitimi ve araştırmanın geliştirilmesi

Tavsiye Kararı 10: Etkileşime yönelik iletişim ağları oluşturmak

d) Eyleme dayalı uluslar arası işbirliği

Tavsiye Kararı 11: Uluslar arası etkileşimi organize etme ve gerçekleştirme

Tavsiye Kararı 12: Politik karar mercilerinin farkındalıklarını arttırmak ve harekete geçirmek

2007 yılında alınan bu kararlar dikkatle incelendiğinde medya okuryazarlığı kavramının öğretmen eğitiminde önemli yer kapladığı görülmektedir. Özellikle de medya eğitiminin temel öğretmen eğitimi ile ilişkilendirilmesi, uygun pedagojik yöntemlerin geliştirilmesi ve toplumdaki tüm paydaşlarla işbirliği içinde olunması hem medya okuryazarı öğretmen yetiştirmek hem de bu bireylerin toplumun diğer kesimleriyle (anne ve babalar vb.) ilişki halinde olmasının önemini vurgulamaktadır. Ayrıca yükseköğretime verilen önem de medya okuryazarı öğretmen yetiştirme konusunda üniversitelere oldukça fazla görev düştüğünü göstermektedir. 
Uluslararası alanda birçok ülkede medya okuryazarlığını destekleyen programlar bulunmasına rağmen ülkemizde bu konuda bir kaç uzman dışında henüz kapsamlı bir çalışma yapılmamıştır. Örneğin, çocuklar kitle iletişim araçları konusunda sadece ilköğretim birinci kademede hayat bilgisi dersleri çerçevesinde oldukça sınırlı bir eğitim almaktadırlar. Oysa Türkiye 1989 yılında Avrupa Birliği eğitimden sorumlu bakanlarla birlikte toplantıya ev sahipliği yapmış ve medya okuryazarlığ geliştirmek için hazırlanan karara imza atmıştır (Avrupa Konseyi Parlamenterler Birliği, 2000; Ertürk \& Akkor Gül, 2006). Bunun yanı sıra medya okuryazarlığı ilk olarak 2003 yılındaki İletişim Şurası'nda gündeme gelmiştir. Eylem Planı düzeyinde çalışan Medya ve Şiddet Çalışma Grubunun sonuç raporunda RTÜK'ün önerisiyle 22 Eylül 2004 tarihinde gündeme gelmiş ve medya okuryazarlı̆̆ dersinin ders programlarına eklenmesi için Milli Eğitim Bakanlığı ile resmi temasa geçilmiştir.

“İlköğretim Seçmeli Medya Okuryazarlığı Dersi Öğretim Programı”da 31 Ağustos 2006 tarihinde MEB Talim ve Terbiye Kurulu'nda görüşülerek kabul edilmiştir. İlköğretimde 6, 7 veya 8. sınıfta haftada bir saat ve seçmeli olarak verilen bu ders 2012 yılında yapılan değişiklikle ilköğretim 7 veya 8 . sinıfta haftada 2 saat ve seçmeli olarak verilmeye devam etmiştir (Altun, 2014). Bu gelişmelerden de anlaşıldığı üzere medya okuryazarlığı eğitimi sadece ilköğretim düzeyinde kalmış, ne okulöncesi ne de yükseköğretimi kapsayacak şekilde genişletilmemiştir. Bunu sonucu olarak da Altun'un 2013 yılında çeşitli branşlardaki okul öncesi ve matematik gibi farklı branşlardaki pek çok sayıda öğretmenle yaptığı çalışma sonunda öğretmenlerin genelde medya okuryazarlığı eğitimini "medya ile öğretim" olarak algıladıkları bulgusuna ulaşılması, çok da şaşırtıcı bir durum değildir. Ayrıca bu çalışmada öğretmenlerin yaklaşık \%70'i medyanın pedagojik katkısını şu şekilde ifade etmektedir: a) dersi zenginleştiren, b) kalıcı öğrenmeyi sağlayan, c) öğrencilerin ilgisini çeken, d) genel kültürü arttıran ve e) bilgiye erişimi kolaylaştıran bir öğretim aracı. Bunun dışında öğretmenlerin medyayı branşlarıyla konu, beceri ve değer ekseninde ilişkilendirmekten ziyade daha çok öğretim aracı/materyali olarak ilişkilendirdikleri görülmektedir. Başka bir deyişle öğretmenlerin bu ifadelerinde ne medya okurluğuna ne de medya yazarlığına yönelik bir vurgu bulunmaktadır.

$\mathrm{Bu}$ çalışmadan ve günlük gözlemlerden yola çıkarak öğretmenlerin medyayı sorgulanabilir, eleştirel olarak okunabilir bir metin olarak ya da öğrencilerin kendi mesajlarını üreterek kendilerini ifade edebilecekleri bir araç olarak algılamadıkları ileri sürülebilir. Çocuklar okul öncesi dönemde, medyanın hem alıcısı hem de sosyal paylaşım siteleri, forum siteleri vb. ortamlarda, yazılı olarak olmasa da fotoğraf ve videolarla medyanın üreticisi ve dağıtıcısı olabilmektedir (Tüzel, 2012). Fakat yapılan alan yazın taraması okulöncesine ve yükseköğretime yönelik yapılan medya okuryazarlığı eğitimi çalışmalarının yetersiz olduğunu göstermiştir (Altun, 2014).

Okulöncesi eğitim alanı ilköğretime temel oluşturması bakımından ayrı bir öneme sahiptir. İnsan gelişiminin en hızlı olduğu süreci kapsayan okulöncesi dönemde alınan eğitimin ileriki yaşlardaki öğrenmeler üzerinde önemli etkilere sahip olduğu bilinmektedir. Okulöncesi eğitim hizmetlerinden beklenen yararın sağlanması, bu programların uygulayıcısı olan öğretmenlerin bu dönemdeki çocuğunun psikomotor, sosyal, duygusal ve bilişsel alan gelişimini en üst düzeye çıkaracak öğrenme ortamını oluşturabilmesine bağlıdır (Tanrıseven, 2013).

Öğretmen adaylarının mesleki yeterliliklerini arttırmada en önemli yollardan biri yükseköğretim kurumlarında gerçekleştirilen uygulamalardır. Hizmet öncesi öğretmen eğitiminde okullarda uygulama etkinlikleri, öğretmen adaylarının lisans öğreniminde öğrendiği bilgi ve becerilerin bizzat okul ve sınıf ortamında uygulamaya konulması ve denenmesi açısından oldukça önemli bir yere sahiptir (YÖK, 2007). 
Altun'un (2014) medya okuryazarlı̆̆ı alan yazın taramasında diğer dikkat çeken bir durumu ise medya okuryazarlığının disiplinler arası pencereden yeterince ele alınmamasıdır. Bu nedenle bu çalışmada yükseköğretimde, okulöncesi öğretmen adaylarıyla, medya okuryazarlığı yaratıcı dramadan yararlanılarak disiplinler arası bir perspektif ile sunulacaktır. Çünkü medya okuryazarı bir bireyde şu özelliklerin bulunması beklenmektedir (Aufderheide, 1993):

$\checkmark$ Medyayı bilinçli, etkili ve kendi yararı için kullanır.

$\checkmark$ Alternatif bilgi kaynakları arar, farklı kaynaklardan gelen bilginin doğruluğunu değerlendirir.

$\checkmark \quad$ Medyanın bireylerin ve toplumların inanç, tavır, davranışlar ve değerler üzerindeki etkisinin bilincindedir.

$\checkmark$ Medyanın fikir, bilgi ve haberi bir başkasının bakış açısıyla aktardı̆̆ı̆ıın farkındadır.

$\checkmark$ Medya mesajlarının belli bir yaratım süreci sonunda oluştuğunun farkındadır.

$\checkmark \quad$ Medya mesajlarının ekonomik, sosyal, politik, tarihi ve estetik gibi çeşitli bağlamlarda üretildiğinin farkındadır.

$\checkmark \quad$ Medyayı kültürü anlamada kaynak olarak görür.

$\checkmark$ Medyanın kendine özgü bir dili olduğunu bilir.

$\checkmark$ Medya karşısında eleştireldir.

$\checkmark$ Bilgiye ulaşma ve kullanmada etik ve yasal konuları bilir.

\section{Medya Okuryazarlığı ve Yaratıcı Drama İlişkisi}

Yukarıda sözü edilen bilgilerin ışı̆̆ında medya okuryazarı bir bireyin; medya okuryazarlığının üç temel basamağ olan "erişim", "analiz etme ve anlama" ve "yeniden oluşturma" ile ilgili yetkinliklere sahip olması gerekmektedir (Buckingham, 2004). Hobbs’un (2010) yayınlamış olduğu dijital ve medya okuryazarlığı ile ilgili eylem planında ise bu basamaklar beşe çıkarılmıştır. Bunlar (a) erişim, (b) analiz etme \& değerlendirme, (c) yeniden oluşturma, (d) yansıtma ve (e) harekete (eyleme) geçme olarak belirtilmiştir. (Bkz. Tablo-1 ve Şekil-1)

Tablo 1. Dijital ve Medya Okuryazarlı̆̆ının Temel Yetkinlikleri

\begin{tabular}{ll}
\hline Temel Yetkinlikler & Açıklama \\
\hline Erişim & $\begin{array}{l}\text { Medya ve teknolojik aletlere ulaşma ve onları berceriyle kullanma, uygun } \\
\text { ve ilgili bilgileri diğer kişilerle paylaşma }\end{array}$ \\
\hline Analiz Etme \& & Mesajları anlama ve mesajın potansiyel etkileri ve sonuçlarını düşünerek \\
Değerlendirme & mesajın kalitesini, doğruluğunu, güvenirliliğini ve bakış açısını analiz \\
& etmek için kritik düşünme becerilerini kullanma \\
\hline Yeniden Oluşturma & Amacın, hedef kitlenin ve yeniden tasarlama tekniklerinin farkında \\
& olup yaratıcılığını ve kendini ifade etmedeki güvenini kullanarak içeriği \\
& yeniden tasarlama ya da ortaya çıkarma \\
\hline Yansıtma & Sosyal sorumlulukları ve etik değerleri kişinin özlük, yaşam deneyimi ve \\
& iletişimle ilgili tavır ve davranışlarına uygulama \\
\hline Harekete (Eyleme) Geçme & $\begin{array}{l}\text { Bilgi paylaşmak ve aile, çalışma ortamı ve topluluklardaki problemleri } \\
\text { çözmek için bireysel ve işbirliği içinde çalışma ve yerel, bölgesel, ulusal } \\
\text { ve uluslararası topluluklara bir üye olarak katılma }\end{array}$ \\
\hline
\end{tabular}




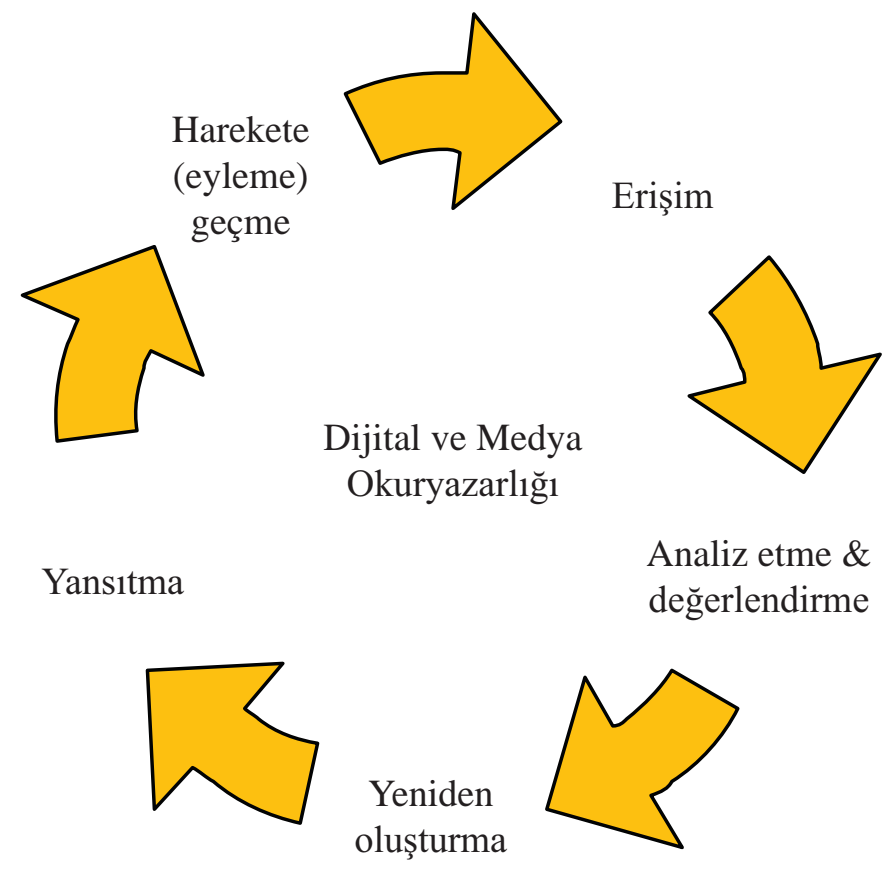

Şekil 1. Dijital ve Medya Okuryazarlı̆̆ının Temel Yetkinlikleri

Bu tablo ve şekle ek olarak Avrupa Birliği Komisyonu (2009) bireylerin medya okuryazarlığ seviyelerini çevresel ve bireysel boyutları göz önünde bulundurarak (a) temel (b) orta ve (c) ileri düzey olarak belirlemiştir (Bkz.Tablo-2).

Tablo 2. Medya Okuryazarlı̆̆ı Yetkinlik Seviyeleri

\begin{tabular}{|c|c|c|}
\hline \multirow[t]{2}{*}{ Seviye } & \multicolumn{2}{|l|}{ Boyutlar } \\
\hline & Bireysel & Çevresel \\
\hline Temel & $\begin{array}{l}\text { Birey medyanın temel kullanımına izin veren becerilere sahiptir. } \\
\text { Kullanıcı medyanın işlevini bilir, temel kodların anlamını çözer ve } \\
\text { bunu spesifik sonuçlar için kullanır. Kullanıcı elde edilen bilginin } \\
\text { kritik bir şekilde analiz edilmesinde kısıtlı bir kapasiteye sahiptir. } \\
\text { İletişimsel kapasitesini medya aracıllğıyla kullanması sınırlıdır. }\end{array}$ & $\begin{array}{l}\text { Çevre medya } \\
\text { okuryazarlığının gelişmesi } \\
\text { için yeterli uyaranı } \\
\text { sağlamamaktadır. }\end{array}$ \\
\hline Orta & $\begin{array}{l}\text { Birey medyanın işlevlerini derinlemesine bilerek onu orta } \\
\text { düzeyde kullanma ve karmaşı işlemleri gerçekleştirme } \\
\text { kapasitesine sahiptir. Kullanıcı gerekli bilgiyi nasıl elde edeceğini } \\
\text { ve değerlendireceğini bilir ve bu bilginin araştırma yollarını } \\
\text { değerlendirir. Kullanıc aktif bir üretici ve sürece sosyal olarak } \\
\text { katılan bir kişidir. }\end{array}$ & $\begin{array}{l}\text { Çevre bir kaç uyaranı } \\
\text { sağlamaktadır fakat tek tük } \\
\text { ve düzensiz bir şekilde. }\end{array}$ \\
\hline İleri & $\begin{array}{l}\text { Birey medya kullanımını etkileyen yasal koşullara önem verip } \\
\text { ve bunların farkında olup onu kullanma konusunda bir uzmandır. } \\
\text { Kullanıcı ulaşmış olduğu bilginin tekniği ve dili hakkında detaylı } \\
\text { bilgi sahibidir ve üretim ve iletişimle ilgili mesajları ve iletişimsel } \\
\text { ilişkilerini etkileyen koşulları analiz edebilir ve dönüştürebilir. } \\
\text { Kullanıcı kamu alanında sorunlarını çözmesine izin verecek } \\
\text { grupların işbirliğini harekete geçirici kapasiteye sahiptir. }\end{array}$ & $\begin{array}{l}\text { Çevre sistematik uyaran } \\
\text { sağlamaktadır. Medya } \\
\text { okuryazarı bir toplum } \\
\text { yetiştirmek için eylemler } \\
\text { düzenlemektedir. }\end{array}$ \\
\hline
\end{tabular}


Yukarıda belirtilen özellikler bir bütün olarak ele alındığında yaratıcı drama yöntemiyle okul öncesi öğretmen adaylarının medya okuryazarlığı konusunda etkili bir biçimde desteklenebileceği görülmektedir. Çünkü Hobbs (2001) medya okuryazarlığı eğitiminin şu özellikleri içerdiğini ifade eder: (a) sorgulamaya dayalı eğitim, (b) öğrenci merkezli öğrenme, (c) gruplarla işbirliği halinde problem çözme, (d) standart testlerin alternatiflerinin kullanılması ve (e) entegre edilmiş (birleştirilmiş) eğitim programı. Hobbs’un bu ifadesi de yaratıcı dramanın genel amaçları ile medya okuryazarı bir bireyin yetişmesini sağlayan eğitim programının özelliklerinin örtüştüğü görüşünü desteklemektedir. Adıgüzel (2013)'e göre, yaratıcı dramanın genel amacı çocukların ergenlerin ve gençlerin canlandırmalar yoluyla gerçek dünya ile kurgusal dünya arasında gidip gelmelerini olanaklı kılarak bir bilinçlenme ve kültürlenme süreci içerisinde "her alanda yaratıcı", "kendine yetebilen", "kendini tanıyan", "çevresiyle iletişim kurabilen ve bunu geliştirebilen", "ifade gücü ve biçimleri artmış", "imgesel düşünebilen”, "estetik kaygı" ve "demokratik tutum ve davranışları gelişmiş" bireyler yetiştirmektir. Ayrıca yaratıcı drama ile ilgili yapılan çalışmalar yaratıcı dramanın kişiyi bir bütün olarak öğrenme sürecine dâhil olmasını sağlayan bir öğretim metodu olduğunu da göstermektedir (Littledyke, 1998; McNaughton 2004).

Bireyler yapmış oldukları ya da yaptıkları faaliyetlerin etkisini yaratıcı drama yoluyla hem gerçek ve hem hayali olarak keşfetme olanağına sahiptirler (Littledyke, 2008). O’Neill (1995) bu noktada yaratıcı dramanın yaklaşımlarından birisi olan süreçsel dramaya dikkat çekmiş ve bu yaklaşımı çalışmalarında kullanılmıştır. Bunun nedeni ise O’Neill (1995)'e göre süreçsel dramada imgesel bir dünya oluşturulur ve katılımcıyı ilgilendiren herhangi bir sorun bu imgesel dünya içerisinde ele alınır. Katılımcı bu dünya içinde, gerçek duygularından yola çıkarak oluşturduğu kurmaca durumlarda, kurmaca karakterler üzerinden belli bir tutum içerisine girer ve bu seçimin katılımcının gerçek dünyasındaki tutumunu da etkileyeceği varsayılır.

Bütün bu bilgilerin 1şığında, bu araştırmada süreçsel drama yaklaşımı kullanılarak oturumlar yapılandırılmıştır. Süreçsel dramanın bütün süreci kapsayan, herhangi bir metnin söz konusu olmaması ve bir metinden bağımsız olarak katılımcıyı ilgilendiren bir problemin (medya içinde sıkışıp kalmış bir bireyin nasıl medya okuryazarı olacağı), tematik bir yolla canlandırılması ve sembolik olarak anlatma gibi sanatsal olanakları sürece katılarak ele alınması bu yaklaşımın kullanılmasında belirleyici olmuştur.

Özetle, yapılan alanyazın taraması medya okuryazarlı̆̆ı ile ilgili üniversite öğrencilerini hedef alan bir dersin yüksek öğretimde yer almadığını göstermiştir. Bu nedenle 2015-2016 akademik yılının bahar döneminde okulöncesi öğretmenliği bölümü 3. ve 4.sınıf öğrencilerine "Çocuk ve Medya" adlı bir seçmeli ders açılmıştır. Bu seçmeli ders kapsamında üniversite öğrencilerinin bu süreci içselleştirmesi ve aktif olarak sürece katılımlarını sağlamak amacıyla dersin bir kısmı süreçsel drama oturumlarıyla biçimlendirilmiştir. Diğer bir ifadeyle, bu çalışmada "Çocuk ve Medya" seçmeli dersi kapsamında medya okuryazarlığı ile ilgili süreçsel drama atölyelerinin okulöncesi 3. ve 4. sınıf öğrencilerinin medya okuryazarlık seviyelerine etkilerini araştırmak amaçlanmıştır. Bu amaç doğrultusunda yöntem kısmında belirtilen araştırma sorusu ve alt araştırma sorularının cevapları aranmıştır. 


\section{Yöntem}

$\mathrm{Bu}$ araştırmada nitel araştırma yöntemlerinden eylem araştırması kullanılmıştır. Eylem araştırması çeşitlerinden de teknik/bilimsel/işbirlikçi eylem araştırması kullanılmıştır (Berg, 2001). Diğer bir ifadeyle, bu çalışmanın yöntemini şu ana kadar yükseköğretimde yer almayan seçmeli bir dersin açılması ve bu ders kapsamında farklı bir öğretim metodunun kullanılarak okulöncesi öğretmen adayları üzerindeki etkisinin araştırılması belirlemiştir. Yapılan bu araştırma üç kısımdan oluşmaktadır. Bunlar "uygulama öncesi”, "uygulama” ve "uygulama sonrası” olarak ifade edilmiştir. $\mathrm{Bu}$ çalışmanın uygulama kısmı; haftada üçer saatlik oturumlarla 7 haftalık bir süreçten oluşmuş, süreçsel drama yaklaşımı yöntem olarak kullanılmıştır. Uygulama öncesi ve uygulama sonrasında verilerin toplanması ve analiz edilmesi kısmında ise nitel araştırma deseni kullanılmıştır. Ayrıca bu ders öncesinde görüşme sorularıyla katılımcıların bu ders ile ilgili beklentileri de belirlenmeye çalışılmış ve bu bulgular doğrultusunda drama atölyeleri tekrar gözden geçirilmiştir.

Araştırma Sorusu: Medya okuryazarlığı ile ilgili süreçsel drama oturumlarının okulöncesi öğretmen adaylarının medya okuryazarlığı seviyelerine etkileri nelerdir?

a) Medya okuryazarlığı ile ilgili süreçsel drama oturumlarının okulöncesi öğretmen adaylarının medya okuryazarlığı yetkinlik seviyelerine etkileri nelerdir?

b) Medya okuryazarlığı ile ilgili süreçsel drama oturumlarının okulöncesi öğretmen adaylarının medya okuryazarlığ 1 temel yetkinliklerine etkileri nelerdir?

\section{Katılımcilar}

Bu çalışmaya, bir devlet üniversitesinin okulöncesi öğretmenliği bölümünde öğrenim gören 16 üçüncü ve dördüncü sınıf öğrencisi katılmıştır. Katılımcılardan 15 kişi kadın ve 1 kişi erkektir. Katılımcılar kolay ulaşılabilir durum örneklenmesi ile seçilmiştir (Merriam, 2009).

\section{Veri Toplama Araçları}

Bu çalışmada iki tip nitel veri toplama araçları kullanılmıştır. Bunlar:

a) Katılımcıların Paylaşımları: Bu araştırmada ana veri katılımcıların uygulama boyunca her oturumdan sonra o oturumla ilgili yazmış oldukları 350-500 kelimelik paylaşımlarıdır. Bu yazılar tüm katılımcılar tarafından elektronik ortamda oluşturulmuş forum platformunda paylaşılmıştır. Başka bir deyişle, katılımcılar için diğer arkadaşlarının o oturumla ilgili yazmış olduklarını görüp yeri geldiğinde ona yorum yapabilecek etkileşimli bir paylaşım ortamı oluşturulmuştur.

b) Dokümanlar: Katılımcıların çalışma boyunca ürettikleri, mektup, gazete, afişler, poster vb. dir.

\section{Uygulama}

Oturumlar, süreçsel drama yaklaşımına uygun bir bütünsellik içinde yapılandırılmıştır. Haftada bir gün üçer saat süren yedi oturumda; ele alınan ana temaya (medya okuryazarlığına) bağlı kalınarak, "görsel ve işitsel medyanın (televizyon-diziler) etkisinin incelenmesi”, "basılı medyanın (gazete-haber) etkisinin incelenmesi", "sosyal medyanın (facebook, instagram v.b) etkisinin incelenmesi”, "çocuk ve medya okuryazarllğı konusunun incelenmesi” ve "çocuk ve medya okuryazarlı̆̆ 1 ile ilgili etkinliklerin oluşturulması" üzerinde durulmuştur. Oturum planında beş başlığa yer verilmiştir. Bu başlıklar; durumlar/anlar, teknikler, yönerge, roller ve araçlar/gereçlerdir. Örnek plan için bakınız Ek-1. 
Adıgüzel (2013)'e göre süreçsel dramada her öykünün her zaman bir öncesi vardır. Bu nedenle de ilk oturuma durumu özetleyen rol kartlarıyla başlanmıştır. Bunun yanı sıra süreçsel dramanın yapısı gereği önceden kurgulanan atölyelerdeki olası temel akış planı, katılımcıların ilgi ve istekleri doğrultusunda tekrar ele alınıp gerekli düzenlemeler yapılarak uygulanmıştır.

\section{Verilerin Analizi}

Ana veri olan katılımcıların paylaşımlarından elde edilen veriler ve dokümanlar içerik analizi kullanarak analiz edilmiştir. Ana verilerin geçerliliği için çeşitlemeden, güvenirliliği için iki farklı kişi tarafından yapılan kodlamadan yararlanılmıştır.

\section{Bulgular ve Yorum}

Bulguları ortaya çıkaran veri toplama araçları olarak; katılımcıların paylaşımları ve katılımcıların çalışma boyunca ürettikleri; mektup, gazete, afişler, poster gibi dokümanlar kullanılmıştır. Bulguların yorumlanmasında ise içerik analizi yöntemi kullanılmıştır. Araştırma sorusu baz alınarak öncellikle her atölye sonunda yazılan katılımcıların paylaşımlarıyla daha sonra ise katılımcıların ürettikleri dokümanlarla ilgili bulgulara yer verilecektir.

\section{I) Katılımcıların Paylaşımları}

Katılımcılar her haftanın sonunda o hafta yapılan atölyelerle ilgili belirlenmiş konularda çevrimiçi ortamda oluşturulan forumda paylaşımlarını yapmışlardır. Bu paylaşımların konuları şu şekildedir:

(a) Bugün öğrendim ki...,

(b) Süreci bir bütün olarak değerlendirdiğinizde, bugüne dair kendim olarak hissettiklerim...,bugüne dair çocuk olarak hissettiklerim...bugüne dair öğretmen olarak hissettiklerim...,bugüne dair veli olarak hissettiklerim...,bugüne dair yönetici (müdür, il / ilçe milli eğitim müdürü, kaymakam) olarak hissettiklerim...,

(c) Bugün ile ilgili siz bir rüya görseydiniz neleri görmek isterdiniz ya da görmeyi beklerdiniz? Uyandığınızda nelerin değişmesini isterdiniz/beklerdiniz?

(d) Bugünkü süreçte yaşadıklarınızı düşündüğünüzde okul öncesi öğretmeni olarak velilere bir örnek olay incelemesi üzerinden seminer verseniz özellikle basılı ve sosyal medyayı içeren nasıl bir örnek olay oluştururdunuz/kurgulardınız ya da var olan bir örnek olayı (dersimiz dışında) paylaşırdınız? Sebepleriyle açıklar mısınız?

(e)“Ankara İl Milli Eğitim Müdürlüğü, kendi bünyesinde oluşturulan "çocuk ve medya” kurulundaki öğretmen arkadaşlarınızla bu konudaki deneyimlerinizi paylaşmanızı ve onlara (kendi belirlediğiniz yaş grubu için) örnek bir aylık plan oluşturmanızı istiyor. Bu aylık planda hangi kazanım ve göstergelere yer vereceksiniz? Bunları Hobbs'un kriterleriyle nasıl eşleştirecekseniz? Hangi kavramlara, belirli gün ve haftaya, alan gezisine ve aile katılımına yer vereceksiniz?”

(f) "Bugünkü süreci düşündügünüzde geleceğin öğretmenleri olarak medya okuryazarllğ 1 ile ilgili eğitimin ne zaman başlaması, ne kadar sürmesi, hangi aşamaları ve konuları içermesi, hangi amaçları hedef alması (Hobbs'un kriterlerini düşündüğünüzde) gerektiğini düşünüyorsunuz? Sebepleriyle birlikte açıklar mısınız? Bu kriterleri içeren bir eğitim programı tasarlarsanız hangi eğitim felsefesi(leri)nden ya da kuram(lar)ından (öğretim metodu ve tekniklerinden yararlanırdınız?" ve 
(g) "Yedi hafta boyunca birlikte yürüttüğümüz çocuk ve medya dersini düşündüğünüzde, erken çocukluk döneminde medya okuryazarlığı ile ilgili bir uzman olarak sizden bu konuyla ilgili görüş istense şu an öğretmen olanlara, gelecekte öğretmen olacaklara, ailelere, program düzenleyicilere, sivil toplum kuruluşlarına ve üniversitelere neler söylerdiniz?"

Katılımcıların bu paylaşımları araştırma sorusu baz alınarak temel yetkinlikleri Hobbs'un kriterlerine göre ve medya okuryazarlık yetkinlik seviyeleri ise AB komisyonunun belirttiği medya okuryazarlığ 1 basamaklarına göre analiz edilmiş ve bulgular her haftanın paylaşımlarından tesadüfi olarak seçilen örneklerle aşağıdaki gibi sunulmuştur.

\section{a) Birinci Atölyeye ait Bulgular}

Birinci atölyenin sonunda yazılan “Bugün Öğrendim ki...”ile ilgili paylaşımlar analiz edildiğinde katılımcıların hepsinin $(n=16)$ Hobbs'un (2010) medya okuryazarllğ 1 temel yetkinliklerinden "erişim", "analiz etme \& değerlendirme" ve "yeniden oluşturma" ve büyük bir kısmının (n = 12) "yansıtma" ve "harekete (eyleme)" geçmeye değindiği görülmüştür. Avrupa Birliğinin oluşturmuş olduğu medya okuryazarlılığ 1 yetkinlik seviyelerine göre çoğunluğu $(n=11)$ "ileri” düzeyken bir kısmı $(n=5)$ da "orta" düzeyde bulunmaktadır. Diğer bir ifadeyle katılımcıların çoğunluğu medyanın aktif ve bilinçli kullanıcısı olup medya kullanımını etkileyen yasal koşullara önem verip ve bunların farkında olup onu kullanma konusunda bir uzmandır. Ayrıca ulaşmış oldukları bilginin tekniği ve dili hakkında detaylı bilgi sahibidir. Üretim ve iletişimle ilgili mesajları ve iletişimsel ilişkilerini etkileyen koşulları analiz edebilir ve dönüştürebilir. ( Bakınız Tablo-2)

Katılımcı-3 (İleri düzey): ...10 yaşındaki kuzenim, yetimhanede yaşayan birtakım çocukların ya da ailesinden koparılan ve hizmetçi/dilenci gibi çalıştırılan çocukların acı dolu hikâyelerini gözlerini açarak zevkle izliyor (analiz etme \& değerlendirme) ve biz de yetișkinler olarak buna bir müdahalede bulunmuyor ya da bu durumdan bir ders çıkarmasını sağlamıorsak, bu tamamen bizim suçumuz. Bu derste öğrendiğim en önemli nokta da budur. (yansitma ve harekete (eyleme) geçme)

Bu kısımda tüm katılımcıların paylaşımlarından elde edilen veriler şu şekilde yorumlanabilinir. Katılımcıların bazılarının önceden izlediği için incelenen dizilerden haberdar olduğu ancak bir kısmının da haberdar olmadığı görülmüştür. Aralarında bu dizileri izleyenler de olsa şu ana kadar katılımcıların hiçbirinin dizilerin konularına eleştirel gözle bakmadıkları görülmüştür. Bu oturum sırasında dizileri izleyip inceleme fırsatını bulduklarını ifade etmişlerdir. İncelemelerin sonrasında ise bir eğitimci olarak televizyonda gösterilenler programlar hakkında bilgi sahibi olup bununla ilgili çocuklarla ve aileleriyle paylaşımlarda bulunulmasının ve bu konuda harekete geçilmesinin önemini vurgulanmışlardır.

\section{(b) İkinci Atölyeye ait Bulgular}

İkinci atölyenin sonunda yazılan "Bugüne dair ... olarak hissettiklerim...”ile ilgili paylaşımlar analiz edildiğinde katılımcıların hepsinin ( $n=16)$ Hobbs'un (2010) medya okuryazarlığı temel yetkinliklerinden "erişim", "analiz etme \& değerlendirme" ve "yeniden oluşturma" ve bir kısmının (n=10) "yansıtma” ve "harekete (eyleme)" geçmeye değindiği görülmüştür. Avrupa Birliğinin oluşturmuş olduğu medya okuryazarl1lı̆̆ 1 yetkinlik seviyelerine göre çoğunluğu $(n=10)$ "ileri” düzeyken bir kısmı (n=6) da "orta" düzeyde bulunmaktadır. 
Katılımcı-5(İleri düzey).... Uyarlama yapılmasına karar verilmiști fakat bu dizinin tarihimizi yansıtmadiğını düsünürsek ve içeriğinde çocukları çokça etkileyen unsurların bulunduğu bu dizinin çocukların gelişimlerini etkilemeyecek șekilde nasıl uyarlanabileceğinden emin değildim. (Analiz etme \& değerlendirme, yeniden oluşturma) ...C Cocukların yapmaktan keyif almadıkları, yaparken mutlu olmadıkları provaları yaparken ve onları yapmak zorunda oldukları bir gösteriye hazırlamak ögretmen olarak bana kötü hissettirirdi. Bu drama sayesinde bir kez daha gelecekte böyle bir olaya kesinlikle izin veremeyeceğimi ve böyle șeylere kesinlikle engel olacağımı hissettim. (harekete (eyleme) geçme)

Bu kısımdaki tüm katılımcıların paylaşımlarından elde edilen veriler incelendiğinde şu şekilde yorumlanabilinir. Katılımcıların drama süreci ile ilgili olarak karmaşık duygular içinde olduklarını, kendilerini çelişki içinde hissettiklerini ve genel olarak süreçten kaynaklı yapmak istemedikleri bir şeyi yapmanın verdiği mutsuzluk ve çaresizlik içinde oldukları göze çarpıyor. Bunun yansıra seçilen dizinin neden uygun olmadığına da vurgu yapılıyor. Çalışmanın birincil hedeflerinden birisi olmamasına rağmen okul öncesi eğitim kurumlarında yapılan yılsonu gösterilerinin çocukların gelişimsel düzeyine uygun olmadığı ve onları süreçten zevk almaktan uzaklaştırıp strese ve özgüven eksikliğine sürüklediğine vurgu yapılıyor. Bunun yanı sıra katılımcıların çoğunluğunun gösterinin gazetelerde yayınlanması sürecinde yasal yollara başvurma ve öğretmen olarak haklarını arama konusunda kararlı oldukları görülmüştür.

\section{c) Üçüncü Atölyeye ait Bulgular}

Üçüncü atölyenin sonunda“Bugün ile ilgili bir rüya görseydiniz...” ile ilgili paylaşımlar analiz edildiğinde katılımcıların hepsinin ( $n=16)$ Hobbs'un (2010) medya okuryazarlı̆̆ 1 temel yetkinliklerinden tümüne -"erişim”, "analiz etme \& değerlendirme", "yeniden oluşturma", "yansitma" ve "harekete (eyleme)" geçme- değindiği görülmüştür. Paylaşımlar incelendiğinde katılımcıların özellikle yansıtma ve harekete (eyleme) geçme basamaklarına daha çok vurgu yaptıkları görülmüştür. Avrupa Birliğinin oluşturmuş olduğu medya okuryazarlılığı yetkinlik seviyelerine göre ise katılımcıların tümü ( $\mathrm{n=16)}$ "ileri” düzeyde bulunmaktadır.

Katılımcl-11: (İleri)....Mesele çocuklar olunca oldukça tepkiye maruz kalmıș yapım sirketi ve bu tepkiler sonucu ise birakın reytinglerinin artmasinı çocukları kullandıkları için yapım șirketinin diziyi kaldırıp yüklü bir miktar tazminat ödemesi için de imza kampanyası başlatılmış. (harekete (eyleme) geçme) Tabi ben de hemen giderek imza kampanyasına katılmak istedim fakat bir engelle daha karşılaştım. Imzaya kayıt yapmam için neden göstermem gerekiyormuş sonrasında da sosyal medya hesaplarımda bunu paylaşmam. Uzunca bir yazının altına imzamı da ekleyerek daha sonra tüm formu da sosyal medya aracılığıyla paylașarak katılımımı gerçekleștirdim (yansitma).

Bu kısımda tüm katılımcıların paylaşımlarından elde edilen veriler şu şekilde yorumlanabilinir. Katılımcıların olumsuz durumları olumluya çevirmeye çalıştıkları ve bununla ilgili alternatif çözüm yolları ürettikleri görülmüştür. Ayrıca paylaşımlar analiz edildiğinde katılımcıların var olan durum(lar) daki aksaklıkları kolaylıkla tespit edip ve bunları ifade ettikleri de görülmüştür. Bunun dışında oturumların direkt amacıyla ilgili olmamasına rağmen süreç içinde aktif oldukları canlandırmaların, oyunların ve kendi oluşturdukları haberlerin (oturumdaki olumsuz durumu olumluya çeviren) ... v.b kısımlarının gördükleri rüyalarında da aynen olmasını istediklerini belirtmişlerdir. 


\section{d) Dördüncü Atölyeye ait bulgular}

Dördüncü atölyenin sonunda “...Okul öncesi öğretmeni olarak velilere bir örnek olay incelemesi üzerinden seminer verseniz ..." ile igili paylaşımlar analiz edildiğinde katılımcıların hepsinin(n=16) Hobbs'un(2010) medya okuryazarlığı temel yetkinliklerinin tümüne-"erişim", "analiz etme \& değerlendirme", "yeniden oluşturma", "yansıtma” ve "harekete (eyleme)" geçme-değindiği görülmüş̧ür. Paylaşımlar incelendiğinde katılımcıların özellikle analiz etme\&değerlendirme, yanıstma ve harekete (eyleme) geçme basamaklarına daha çok vurgu yaptıkları görülmüştür. Avrupa Birliğinin oluşturmuş olduğu medya okuryazarlılığ 1 yetkinlik seviyelerine göre ise katılımcıların tümü (n=16) "ileri” düzeyde bulunmaktadır.

Katılımcı-15: (İleri) ... Ben bir okulöncesi öğretmeni olarak velilere bu konuyla ilgili seminer verecek olsam örnek olay olarak geçenlerde duyduğum bir oyunla ilgili bir olay kullanabilirdim. Bu olay bir sosyal medya sitesi olan Facebook'ta oynanan bir oyunla ilgili. ... Bir çocuk bu oyunu oynamaya bassliyor ve diğer karakterlerin gerçek kișiler olduğunu bile anlamıvor çünkü karakterler çizgi șeklinde. Daha sonra bu çocuk kendinden yașça büyük kișilerin cinsel içerikli konușmalarını okuyor. Çocuğun yașl, cinsiyeti, nerede okuduğu ve nerede oturduğu kendinden yașça büyük insanlarca sorulmaya başlıyor. Bu kişiler kendi yașlarını çocukların yașlarına yakın söylüyor ve çocukla da cinsel içerikli konuşmalar yapıyor. Bu kişiler çocukların çoğu bilgisini ögrendiğini için onlara dıșarıda da zarar verebiliyor (analiz etme \& değerlendirme). Örnek olay olarak geçenlerde ekşi sözlükte okuduğum bir olayı ailelere gösterebilirim...

... Ben bu örnek olayı aileleri biraz bilinçlendirmek ve onların masum gördüğü çocukların oynamasında sakınca görmediği bazı oyunların içeriğinin farklı olabileceğini anlatmak için seçtim (yansitma).

Seminerimde ailelere bu oyunla ilgili çıan haberleri gösterebilirim ve beraber açıp bu oyunu oynayabiliriz (erișim) böylece onlar da durumun ciddiyetini daha iyi anlamıș olur. Son olarak, ailelere çocuklarına sosyal medyayı kullanmasına izin verseler dahi sık sık onların hesaplarını kontrol etmelerini ve uygun görmedikleri içeriklere erișimini engellemelerini önerebilirim.(yansitma ve harekete(eyleme) geçme)

Bu kısımda tüm katılımcıların paylaşımlarından elde edilen veriler şu şekilde yorumlanabilir. Katılımcıların çoğunluğunun ailelere verilecek olan seminerlerde var olan güncel olayları (avataria) ve haberleri kullanmayı tercih ettikleri görülmüştür. Ayrıca hikâye oluşturma, kendi örnek olayını oluşturma, mektup yazma v.b gibi tekniklerinden ve yaratıcı drama öğretim yönteminden de yararlanarak seminerlerde kullanacakları bilgilendirmeyi planladıkları görülmüştür. Bunun dışında oturumların direkt amacıyla ilgili olmamasına rağmen katılımcılar ailelerin akıllı telefon, I-pad gibi teknolojik aletler yerine çocuklarıyla birlikte daha fazla zaman geçirmeleri ve çocuklarının dış ortamlardaki etkinliklerini (bahçede oyun oynamak) desteklemeleri gerektiğini belirtmişlerdir.

\section{e) Beşinci Atölyeye ait bulgular}

Beşinci atölyenin sonunda“...örnek bir aylık plan oluşturmanızı istiyor. Bu aylık planda hangi kazanım ve göstergelere yer vereceksiniz?...” ile ilgili paylaşımlar analiz edildiğinde 
katılımcıların hepsinin (n=16) Hobbs'un (2010) medya okuryazarlığı temel yetkinliklerinin tümüne -"erişim”, "analiz etme \& değerlendirme", "yeniden oluşturma", "yansıtma" ve "harekete (eyleme)" geçme-değindiği görülmüştür. Paylaşımlar incelendiğinde katılımcıların özellikle analiz etme \& değerlendirme ve yeniden oluşturma basamaklarına daha çok vurgu yaptıkları görülmüştür. Avrupa Birliğinin oluşturmuş olduğu medya okuryazarlılı̆̆ yetkinlik seviyelerine göre ise katılımc1ların nerdeyse tümü (n=14) “ileri” düzeyde bulunurken bir kısmı $(\mathrm{n}=2)$ "orta” düzeyde bulunmaktadır.

Katılımcı-7: (İleri)... Bu yazıda sizlere şu ana kadar medya ile ilgili elde ettiğim deneyimlerimden bahsedeceğim. Öncelikle medya türlerini, kaynaklarını ve içeriklerini öğrenmemiz gerekiyor. Özellikle bu türlerden çocuklar hangisi ile daha çok ilgileniyor, ürünler ve içeriklerini göz önünde bulundurmak daha önemli. Cocukların nelerle daha çok ilgilendiğini bildiğimizde etkilerine daha aza indirmek daha kolay olacaktır diye düșünüyorum. (analiz etme \& değerlendirme) Hatta sinıfta birinin üzerinde konuşulabilir. Bu konuşma sırasında sorabileceğimiz önemli sorular var. Sizler için onları sıralıyorum.

Sence arkadașın bunu neden beğendi/ beğenmedi?

Sence bu kitabi/ çizgi filmi/ sarklyı kim için yapmıșlar?

Sen bunu neden beğendin/ beğenmedin?

Ahmet'in düsüncesi seninkinden nasil farklı?

Bu afiși biri hazırlamıs. Peki, hazırlayan kiși kimlerin bakmasın istemis olabilir? Neden? (yeniden olusturma)

Bunun dıșında bir medya türünü kullanırken dikkat etmemiz gereken noktalar vardır. Öncelikle sınıfta çektiğimiz bir fotoğraf veya video, yazılı bir metin hazırladığımızda, slnıfımızı için bir poster ya da bașka bir görsel hazırladığımızda bir medya üretmis. oluyoruz. İlk olarak, çektiğimiz video ve fotoğraflar üzerinde duracă̆ım. Fotoğraf karesinde nelerin ve kimlerin olduğu çok önemlidir. Sinıftaki bir çocuğumuzun veya etkinliğinin fotoğrafinı, videosunu çektiğimizde aileden alacă̆ımı izin yeterli olmayacaktır. Bir birey olarak çocuğumuzun ne istediği ve hissettiği önemlidir. Sinıfta kullandiğımız diğer medyaların da içeriği dikkatle seçilmiş olmalıdır. (yansıtma ve "harekete (eyleme)" geçme)...

Bu kısımda tüm katılımcıların paylaşımlarından elde edilen veriler şu şekilde yorumlanabilir. Katılımcıların çoğunluğunun aylık plan hazırlarken süreç içinde kazanmış oldukları deneyimlerinden yola çıkmışlardır. Planlarını belirli gün ve haftalardan yararlanarak oluşturdukları ve aile katılımı ve alan gezileriyle destekledikleri tespit edilmiştir. Ayrıca planları hazırlarken birçok farklı medya tipine (basıl1, görsel ve işitsel, sosyal medya vb.) değinmişlerdir. Bunun yanı sıra medya kullanımı ile ilgili meslektaşlarına tavsiyelerde bulunmaktadırlar.

\section{(f) Altıncı Atölyeye Ait bulgular}

Altıncı atölyenin sonunda "Bugünkü süreci düşündüğünüzde geleceğin öğretmenleri olarak medya okuryazarlığı ile ilgili eğitimin ne zaman başlaması ...”ile ilgili paylaşımlar analiz edildiğinde 
katılımcıların hepsinin ( $\mathrm{n}=16)$ Hobbs'un (2010) medya okuryazarlığı temel yetkinliklerinin tümüne -"erişim", "analiz etme \& değerlendirme", "yeniden oluşturma", "yansıtma" ve "harekete (eyleme)" geçme-değindiği görülmüştür. Paylaşımlar incelendiğinde katılımcıların özellikle analiz etme \& değerlendirme, yeniden oluşturma ve yansıtma basamaklarına daha çok vurgu yaptıkları görülmüştür. Avrupa Birliğinin oluşturmuş olduğu medya okuryazarlılığı yetkinlik seviyelerine göre ise katılımcıların tümü ( $\mathrm{n}=16)$ "ileri” düzeyde bulunmaktadır.

Katılımcı 11: (İleri) Bugünkü süreci ve ögrendiklerimi düşündüğümde gelecekte bir öğretmen olarak medya-okuryazarlı̆̆ına fazlaca odaklanacă̆ım hiç şüphesiz. Medya araçları çocuk doğduğu andan itibaren yașamını etkilediği için medya okur yazarlığının da doğduğu andan itibaren bașlaması gerektiğini düș̈̈nüyorum. Yașamimizın her evresinde var olan medya da varlığını su an hiç yitirmeyecekmis. ve her geçen gün değiserek devam ettiği için medya okur yazarlı̆̆ının da ömür boyu sürmesi gerektiğini düșünüyorum. (yansitma ve harekete (eyleme) geçme)

Hangi aşamaları içereceğ konusun da ise Hobbs'un da bahsettiği gibi erişim olanaklarl, analiz edebilme, değerlendirme ve üretme becerileri olmak üzere devam ettirirdim. Yani Öncelikle çocukların medyaya olan farkındalıklarını artırarak, onu değerlendirebilme ve yeni ürünler olușturarak medyadan en etkili ve sağliklı bir șekilde yararlanmalarını sağlamaya çalıșırdım. Hangi konuları ele alacağım konular ise farklılıklara saygı duymak, etik değerler, özel yaşamın gizliliği, medyadaki sorumluluklarımız, aile içi iletișimimiz ve medya, bilinçli tüketim, bilim ve medya, medya yoluyla dayanıșma ve yardımlașma, medya türleri, medyanın nasıl kullanılacağı ve değerlendirilmesi gerektiği gibi konuları ele alırdım. (yeniden olușturma,yansitma ve harekete (eyleme) geçme) Çünkü medya okuryazarlığı çok yeni bir kavram ve çocuklar da bu durumun farkında olmayarak hayatlarının bir parçası olarak görmektedirler bu sebepten işe öncelikle temel konuları ele alarak en faydalı ve zararsız medya kullanımına gelinmesi gerektiğini düşünüyorum. Medya okur yazarlığındaki hedeflerim ise medya iletilerini doğru anlama ve eleștirel bir bakıș. açısına sahip olma, ifade sekillerini geliștirmek ve son olarak da medya aracıllğgyla üretken bireyler olmalarını sağlamak olacaktır. (analiz etme \& değerlendirme) Ĕger bir eğitim programı hazırlayacak olsam eğitim felsefesi olarak ilerlemecilik, yeniden yapılandırmacılık, gerçekçilik ve sosyal öğrenme çeșitlerini birleștirerek ortaya yeni bir felsefe çıkarmaya çalıșırdım. Öğretim metodu olarak ise daha somut, problem çözmeye dayall, grup çalışmasina teșvik eden ve örnek olayların kullanilabileceği yöntemler seçmek için çaba gösterirdim. Son olarak ise John Dewey'in kuramı olan Araștırma inceleme ve Jeromi Bruner' in kuramı olan bulus yoluyla ögretim teknikleri her zaman için çılıs noktam olurdu. Tüm bunları genel olarak değerlendirdiğimde da çocuk merkezli, ögretmenin rehber ve yönlendirici olacă̆l, yaparak ve yaşayarak ögrenmeyi amaçlayan bir eğitim programı oluşturmak başlıca çıkış noktam olurdu. Ayrıca çocuğun yaşamında oldukça önemli ve büyük yere sahip olan aileleri de bu eğitim programı içine dahil etmeye çalışırdım. Çünkü öğretmen olarak bizler bir şeyler yapmış ya da farkındalık kazandırmış olsak da ailenin rolü göz ardı edilemez bir gerçektir. Böylelikle okul ve ailenin eğitilmesiyle birlikte ișbirlikçi bir yaklașımla çocuklara medya okuryazarliğg kazandırllabilinir (yansitma ve harekete 'eyleme" geçme). 
$\mathrm{Bu}$ kısımdaki tüm katılımcıların paylaşımlarından elde edilen veriler şu şekilde yorumlanabilinir. Katılımcıların nerdeyse tümünün 2 yaşına kadar çocukların medyaya maruz bırakılmaması ve 2 yaşından itibaren de medya okuryazarlılı̆̆ ile ilgili eğitime başlanması gerektiğini savunmaktadır. Bunun yanı sıra birçok katılımcı medya okuryazarlılığı ile ilgili eğitimin yaşam boyu devam etmesi gerektiğini savunmaktadır. Ayrıca bu eğitimin bir bütün olması ve bu nedenle aile eğitiminin de bu bütünün içinde yer alması gerektiğini savunmaktadırlar. Son olarak da medya okuryazarlığı eğitiminin çocuk merkezli yani çocukların hem zihinsel hem bedensel olarak aktif oldukları bir süreç olması gerektiği ifade edilmektedir.

\section{(f) Yedinci Atölyeye Ait bulgular}

Yedinci atölyenin sonunda "Yedi hafta boyunca birlikte yürüttügümüz çocuk ve medya dersini düşündüğünüzde, erken çocukluk döneminde medya okuryazarlığı ile ilgili bir uzman olarak neler söylerdiniz?"ile ilgili paylaşımlar analiz edildiğinde katılımcıların hepsinin $(n=16)$ Hobbs'un (2010) medya okuryazarlığı temel yetkinliklerinin tümüne -“erişim", "analiz etme \& değerlendirme", "yeniden oluşturma", "yansıtma” ve "harekete (eyleme)" geçme- değindiği görülmüştür. Paylaşımlar incelendiğinde katılımcıların özellikle yansıtma ve harekete etme çok daha fazla vurgu yaptıkları görülmüştür. Avrupa Birliğinin oluşturmuş olduğu medya okuryazarlılığı yetkinlik seviyelerine göre ise katılımcıların tümü ( $\mathrm{n}=16)$ "ileri” düzeyde bulunmaktadır.

Katılımcı 9: (İleri) .Öğrendiğimiz medya okuryazarlığı tanımlamasını temel alarak, etkinlikleri üç aşamaya göre planlamanın gerekliliğine değinirdim çünkü çocukların ilk başta medya araçları yoluyla edindikleri bilgileri anlamaları, sonra yorumlama ve yeni fikirler üretebilmesi doğru sıralamayla konuların yer verilmesine de bağlıdır. Ayrıca, sınıfta bir medya kösesi olușturmanın da iyi bir bașlangıç etkinliği olabileceğini söylerdim.. (yeniden olușturma). Sivil toplum kuruluşlarına önerilerim; velileri medya okuryazarlığı ve bilinçli medya kullanımı hakkında bilgilendirmek için önce bir anket çalışması, sonra da bir proje çalıșması yürütmeleri yönünde olabilirdi. Proje çalı,sması, medya okuryazarlığının ne olduğu ve çocukların nasıl daha doğru bilgilendirileceği hakkında videolar, poster ve broșürler hazırlamayı içerebilirdi. Üniversitelere ise, akademik alanda anaokullarına destek verici çalıșmalar yapılmasını önerirdim. (yeniden oluşturma yansitma ve harekete (eyleme) geçme) Çocuklara medya okuryazarlığı kavramının kazandırllabilmesi için özellikle gazetecilik bölümlerinden uzmanlar anaokullarıyla ișbirliği içinde bir bilgilendirme çalıșması yapabilirlerdi. (yansitma ve harekete (eyleme) geçme) Bu çalışmalar, dönem başında ögretmen ve okulla planlanabilirdi. Çalışmalardan bazıları kolaj calısmalarl, gazete ya da dergileri yorumlayıp bunlart video haline getirme seklinde olabilirdi. (yeniden olusturma) Velilerle reklamlarin ve programlarin olumlu ve olumsuz etkileri üzerine fikir alıșveriși yapılabilirdi. Etkinlikler için konu sıralaması yapılabilirdi. Üniversite bünyesinde ögretmenler ve aileler için kurslar verilebilirdi (yansitma ve harekete 'eyleme' geçme).

Bu kısımda tüm katılımcıların paylaşımlarından elde edilen veriler şu şekilde yorumlanabilir. Çocukların medyanın içine doğduğu ve bu nedenle de medyadaki birçok mesaj(lar)a direkt maruz kaldığı ancak medyanın doğru ve etkili bir biçimde kullanıldığında bu olumsuz etkisi(leri)nin olumluya çevirelebileceği bunun içinde drama oturumlarında da yer alan ve Hobbs (2010) tarafından 
da belirtilen ve okulöncesi dönem çocukları için gerekli olan üç temel yetkinliği -erişim", "analiz etme \& değerlendirme", "yeniden oluşturma"yı içeren veya hedef alan uygulamaların yapılması gerektiği belirtiliyor. Bunu dışında ailelere, öğretmenlere, öğretmen adaylarına, program düzenleyicilerine, sivil toplum kuruluşlarına ve üniversitelere düşen görevleri de medya okuryazarlık temel yetkinlik seviyelerinden harekete geçme ve yansıtma düzeyinde örneklerle açıkladıkları görülmüştür. $\mathrm{Bu}$ kısımda en çarpıcı ifadelerden birisi de medya okuryazarlığı için farkındalık yaratmanın yine medya araçlarının bilgilendirmeye yönelik olarak kullanılabilmesiyle sağlanılabilineceği tespitinin yapılmış olmasıdır. Bunlara ek olarak, katılımcılar, okul öncesi programına medya ile ilgili kapsamlı bir bölümün ayrılması ve bu bölümde medya okuryazarlığı ile ilgili kazanımların ve göstergelerin, kavramların, kelimelerin ve etkinlik örneklerinin sunularak öğretmenlere okulöncesi dönemde medya okuryazarlığı ile ilgili kısa ve uzun süreli amaçlarını belirlemede yardımcı olunması gerektiğine vurgu yapmışlardır.

\section{II) Katılımcıların Çalışma Boyunca Ürettikleri Dokümanlar Afişler}

Araştırma sorusuna görekatılımcıların süreç boyunca ürettikleri dokümanlaranalizedildiğinde katılımcıların hepsinin ( $\mathrm{n}=16)$ Hobbs'un (2010) medya okuryazarlığ 1 temel yetkinliklerinin tümüne -"erişim”, "analiz etme \& değerlendirme", "yeniden oluşturma", "yansıtma” ve "harekete (eyleme)" geçme-değindiği görülmüştür. Avrupa Birliğinin oluşturmuş olduğu medya okuryazarl1lığ yetkinlik seviyelerine göre ise katılımcıların tümü $(n=16)$ “ileri” düzeyde bulunmaktadır. Bunun dışında oturumların direkt amacı olmamasına rağmen çocuk hakları sözleşmesine de değinip vurgu yaptıkları görülmektedir. Aşağıda katılımcıların oturumlar boyunca oluşturdukları doküman örnekleri sunulmaktadır.
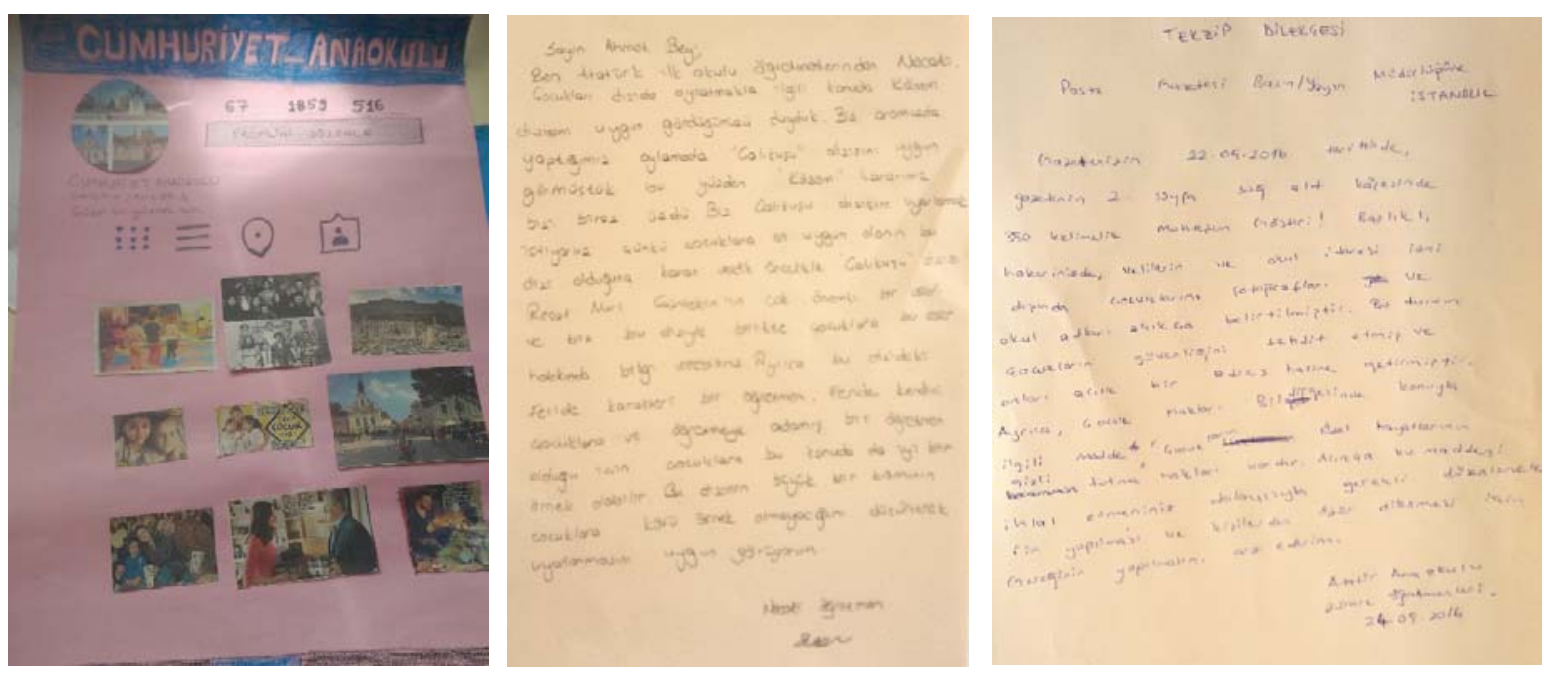

\section{Sonuç ve Öneriler}

Yapılan etkinliklerde görsel ve işitsel medyanın (televizyon-diziler) etkisinin incelenmesi, basılı medyanın (gazete-haber) etkisinin incelenmesi, sosyal medyanın (facebook, instagram) etkisinin incelenmesi, çocuk ve medya okuryazarlığ konusunun incelenmesi ve çocuk ve medya okuryazarlığ 1 ile ilgili etkinliklerin oluşturulması konularına yer verilerek okul öncesi öğretmen adaylarının hem günlük hayatlarındaki hem de gelecekteki çalışma hayatlarındaki medya okuryazarlık seviyelerine etki yapılmıştır. 
Gerek katılımcıların paylaşımları ve gerekse oluşturduğu ürünler çalışmanın amacına ulaştı̆̆ını göstermektedir. Neredeyse tüm katılımcıların Hobbs (2010)'un belirttiği medya okuryazarı bir bireyde bulunması gereken temel yetkinliklerine- erişim, analiz etme \& değerlendirme, yeniden oluşturma, yansıtma ve harekete (eyleme) geçme- eriştiği görülmüştür. Başka bir deyişle medya ve teknolojik aletleri etkili bir şekilde kullanabilen ve bunlarla ilgili bilgileri diğer kişilerle uygun olarak paylaşabilen, medyadaki mesajları anlama ve mesajın potansiyel etkileri ve sonuçlarını düşünerek mesajın kalitesini, doğruluğunu, güvenirliliğini ve bakış açısını analiz etmek için kritik düşünme becerilerini kullanabilen, medya ürünlerindeki amacın, hedef kitlenin ve yeniden tasarlama tekniklerinin farkında olup yaratıcılığını ve kendini ifade etmedeki güvenini kullanarak içeriği yeniden tasarlayabilen, sosyal sorumlulukları ve etik değerleri, kişinin özlük, yaşam deneyimi ve iletişimle ilgili tavır ve davranışlarına uygulayabilen ve bu bilgileri paylaşan ve de aile, çalışma ortamı ve topluluklardaki problemleri çözmek için bireysel ve işbirliği içinde çalışan ve yerel, bölgesel, ulusal ve uluslararası topluluklara bir üye olarak katılan bir bireye doğru değişim görülmüştür.

Avrupa Birliği tarafından oluşturulan yeterlilik seviyelerine göre de katılımcıların tümünün ileri seviye ulaştıkları bulunmuştur. Diğer bir ifadeyle, katılımcıların tümü birey olarak medya kullanımını etkileyen yasal koşullara önem verip ve bunların farkında olup onu kullanma konusunda yeterliliğe sahiptir. Ayrıca bireyler ulaşmış olduğu bilginin tekniği ve dili hakkında detaylı bilgi sahibi olmuştur. Yine bireyler üretim ve iletişimle ilgili mesajları ve iletişimsel ilişkilerini etkileyen koşulları analiz edebilir ve dönüştürebildiği görülmüştür. Sonuç olarak katılımcılar için medya ve medya okuryazarlılı̆̆ bir gündem haline gelmiştir denilebilir. .

Tüm bunlara ek olarak, bu çalışmada yaklaşım açısından süreçsel dramanın uygulanabilirliğine ve medya okuryazarlılığı ile ilişkilendirilmesine ilişkinde bazı sonuçlara ulaşılmıştır. Katılımcıların günlük hayatlarıyla bağdaştıracakları noktalardan yola çıkılarak ve liderin rolde olması, uzman yaklaşımı, rol içinde yazma, afiş tasarlama gibi bu araştırmada doğrudan ya da dolaylı olarak ele alınan yaklaşım ve tekniklerle süreçsel drama yapılandırılırsa, hem akademik hem de pratik açıdan alan yazına önemli katkılar sunabileceği düşünülmektedir. Ayrıca bu çalışma sonucunda süreçsel dramanın medya okuryazarlığı eğitiminde uygun bir pedagojik yaklaşım olduğu söylenebilir.

Bunun dışında bu çalışmanın bulguları sürecin farklı yaş, bölüm, eğitim durumu ve cinsiyetten gelen (genel olarak bu araştırma için seçilmiş katılımcılardan farklı karakteristiklere sahip) katılımcılarla tekrarlanmasından elde edilen bulgularla karşılaştırılabilinir. Ayrıca bu çalışmada nitel araştırma deseni kullanılmış olup diğer araştırmacılar farklı araştırma deseni ve veri toplama teknikleri kullanarak aynı alanda çalışma yapabilirler. Bu araştırmalardan elde edilen sonuçlar da alana farklı açılardan katkılar sunabilir.

Çalışmanın uygulama kısmında ise; süreçsel drama konusunda deneyimli bir liderin öncülüğünde planların oluşturulması, oturumlara (uzman rolünde) alan uzmanlarının çağırılması, araştırmanın değerlendirilmesi aşamasında birçok kaynaktan veri toplanması ve bulguların analizi konusunda çeşitlemenin ve iki farklı kişi tarafından yapılan kodlamanın kullanılması sunulan bulguların geçerliliğini ve güvenirliliği açısından benzer bir yaklaşımla bu alanda araştırma yapacak geleceğin araştırmacılarına ve eğitimcilerine katkı sağlayacağı düşünülmektedir. 


\section{Kaynakça}

Adıgüzel, H. Ö. (2014). Eğitimde yaratıcı drama. (5. Baskı), Ankara: Naturel Yayınevi.

Aufderheide, P. (1993). National leadership conference on media literacy. Conference report. Washington, DC: Aspen Institute.

Avrupa Konseyi Parlamenterler Birliği. (2000). The report of committee on culture and education about media education. Strazburg : Avrupa Komisyonu

Littledyke, M. (1998). Live issues: Drama strategies for personal social and moral education. Birmingham: Questions Publishing Company.

Altun, A. (2009). UNESCO'nun medya okuryazarlığı eğitimi faaliyetlerine toplu bir bakış. Milli Egitim Dergisi, 191(Yaz), 86-107.

Altun, A. (2011). UNESCO’nun medya okuryazarlı̆ğ eğitimi faaliyetlerine toplu bir bakış. Milli Eğitim Dergisi, 1(191), 86-107.

Altun, A. (2014). Medya okur yazarlığı eğitimine yönelik Türkçe yayınlar: Bir bibliyografya denemesi. Ordu Universitesi Sosyal Bilimler Dergisi, 9, 5-15.

Berg, B. L. (2001). Qualitative research methods for the social sciences (4th ed.). Boston: Allynand Bacon.

Buckingham,D.(2004). The media literacy of children and young people a review of the research literature on behalf of Ofcom. Centre for the Study of Children Youth and Media Institute of Education University of London.

Celeot, P.(2009). Study on assessment criteria for media literacy levels. European Commission Directorate General Information Society and Media, Media Literacy Unit.

Ertürk, Y.D., \& Gül. A.A.(2006).Çocuğunuzu televizyona teslim etmeyin. Ankara: Nobel Yayın Dağıtım.

Hobbs, R. (2001). The Great media literacy debates in 2001. Community Media Review 21, 17-23.

Hobbs, R. (2011).Digital and media literacy: A plan of action. The Aspen Institute Communications and Society Program.

Littledkye, M. (2001). Drama and primary science. At the Annual Meeting of the British Educational Research Association. (pp.1-13). England.

Littledyke, M. (2004). Primary children's views on science and environmental issues: examples of environmental cognitive and moral development. Environmental Education Research, 10 (2), 217-235.

Littledkye, M. (2008). Science education for environmental awareness: approaches to integrating cognitive and affective domains. Environmental Education Research, 14(1), 1-17.

Livesey, C. (2011). Defining the mass media. Retrieved November 2014, From http://www.sociology.org.uk/

McNaughton, M. J. (2004). Educational drama in the teaching of education for sustainability. Environmental Education Research, 10(2), 139-155.

Merriam, S.B., (2009). Qualitative research and case study applications in education. San Francisco: Jossey Bass.

O’Neill, C. (1995). Drama Worlds - A Framework For Process Drama, Portsmouth:Heinemann.

Potter, W,J. (2013). Review of literature on media literacy. Sociology Compass, 7(6), 417-435.

Reding, V. (2007). Media literacy: do people really understand how to make the most of blogs,search engines or interactive TV? Commission of the European Communities. Retrieved November 2014, from http:// europa.eu/rapid/pressReleasesAction.do?reference $=\mathrm{IP} / 07 / 1970$

Tanrıseven,I.(2013). Okul uygulamalarının öğretmen adaylarının eğitimde drama kullanımına ilişkin yeterlik algıları üzerindeki etkisi. Kuram ve Uygulamada Eğitim Bilimleri, 13(1), 389-412. 
Tüzel..S.(2012). İlkögretim ikinci kademe Türkçe derslerinde medya okuryazarlı̆̆ı eğitimi: Bir eylem araştırması. Çanakkale: Çanakkale Onsekiz Mart Üniversitesi Eğitim Bilimleri Enstitüsü Yayınlanmamış Doktora Tezi.

UNESCO (1982). Grunwald Declaration on media education. www.unesco.org/education/pdf/MEDIA_E.PDF adresinden 12.02.2013 tarihinde elde edilmiştir.

UNESCO (1984). Media education. Morsy Zaghloul (Editor). Paris: UNESCO

UNESCO (2002). Youth Media Education, Seville, Spain.http://portal.unesco.org/ci/en/files/5680/ 10346121330Seville_Recommendations.rtf/Seville+Recommendations.rtf adresinden 12.02.2013 tarihinde elde edilmiştir.

UNESCO (2007). Parls Agenda Or 12 Recommendations For Media Educatıon. Retrieved November 2014, from http://www.educazionemedia.it/files/4.Parisagendafin_en.pdf

Yavuzer, H. (2013). Sunuş. I. Türkiye Çocuk ve Medya Kongresi Bildiriler Kitabı. İstanbul: Çocuk Vakfı Yayınları.

Yükseköğretim Kurulu (YÖK). (2007). Öğretmen yetiştirme ve eğitim fakülteleri (1982-2007). Ankara: Yazar. 


\section{Ek-1}

\section{I.OTURUM}

Tarih: 10.03.2016

Konu: Görsel ve İşitsel Medyanın (Televizyon-Diziler) Etkisinin İncelenmesi

Süre: 3 saat

Kazanım/lar:

Medya okuryazarlığı kavramı içerisinde yer alan ögelerin neler olduğunu ifade eder.

$\mathrm{Bu}$ ögeleri analiz edip değerlendirir.

$\mathrm{Bu}$ ögelere kendi hayatında nasıl yer vermesi gerektiğinin farkına varır ve bunu uygulamaya dönüştürür.

Lider katılımcılara aşağıdaki ön metni vererek süreci başlatır.

\section{Ön Metin (Rol kartları)*:}

Okulöncesi Öğretmeni, 23 yaşında

Dört yıllık yüksek öğretim maceranızın sonuna gelip okul öncesi öğretmenliği bölümünden mezun oldunuz. Son bir yıl boyunca dişinizi tırnağınıza takıp çalışarak KPSS sınavına girdiniz. Heyecanla sonuçların açıklanmasını bekliyorsunuz. Sonuçlar açıklanıyor oldukça yüksek bir puan alıyorsunuz ve büyük şehirlerden birinde bağımsız devlet okula atanıyorsunuz. İlk yılınızı biraz zor da olsa tamamlamaya çalıştı̆̆ınız şu günlerde okul müdürünüz bütün öğretmenlerle bir toplantı yaparak her birinden sınıflarıyla birlikte bir yıl sonu gösterisi hazırlamasını istiyor. Siz de nasıl bir gösteri hazırlanayabileceğiniz konusunda okuldaki diğer deneyimli meslektaşlarınıza danışıp araştırma yapıyorsunuz. Bu konuda deneyimsiz olduğunuz için okuldaki diğer öğretmenlerin size acemi olarak bakmasından sıkıntılısınız. Siz bu konuyla uğraşırken okul müdürünüz sizi odasına çağırıyor.

Başlangıç Anı: Okul müdürünün odasına girdiğiniz anda doğaçlama başlıyor.

(Medya yapım şirketlerinin birinden gelen e-maili sizinle paylaşıyor. O mailde şunlar yazıyor:) Aşağıda yer almaktadır.

Okul Müdürü, 45 Yaşında

15 yıldır büyük şehirlerin birinde oldukça prestijli bir bağımız anaokulunda görev yapmaktasınız. Görevinizi lakıyla yerine getirmeye çalışıyorsunuz. Veli memnuniyeti sizin için önemli. Siz ve öğretmenleriniz oldukça yoğun çalışıyorlar. Bu yoğun temponun içinde yenilikleri takip etmeye pek vakit bulamıorsunuz. Bu y1l okulunuzdan iş yükünün oldukça fazla olduğunu belirterek ayrılan bir öğretmenizin yerine yeni mezun olmuş bir kişi geliyor. Bu eğitim ve öğretim yılının sonunda öğretmenlerden yıl gösterisi yapmalarını istemek için bir toplantı düzenliyorsunuz. Toplantıdan bir hafta sonra size medya yapım şirketlerinin birinden bir e- mail geliyor. E-maili okuyunca heyecanlanıyorsunuz ve hemen okulunuza yeni gelen öğretmeninizin tiyatro deneyimi olduğunu hatırlıyosunuz. Medya yapım şirketlerinin birinden gelen e-maili paylaşmak ve bu konuyla ilgili konuşmak için yeni gelen öğretmeni odanıza çă̆ırıyorsunuz.

Öğretmen ve müdürün cinsiyeti, adı ve soyadı katılımcılar tarafından belirlendiği için bu kısımda verilmemiştir. 
Başlangıç Anı: Öğretmeniniz odanıza girdiği anda doğaçlama başlıyor.

Medya yapım şirketlerinin birinden gelen e-mailide şunlar yazıyor:

Merhaba Hanım,

Bu e-maili yapım şirketi adına size göndermekteyim. Bu şirkette halka ilişkiler departmanında reklam kısmından sorumluyum. Sizden şu anda TV yayınlanmakta olan ve yapım şirketimiz tarafından desteklenen dizilerden. nın retingini artırmak için o dizinin önemli karakterleri içeren bir bölümünü yıl sonu gösterisinde canlandırmanızı istiyoruz. Bu gösteri için gerekli kostümler ve gösterinin yapılacağı yer ile ilgili bütün düzlenmeleri şirketimiz üstlenecektir. Ayrica okulunuza. TL bağışta bulunacaktır. Eğer size yapmış olduğumuz bu teklifi kabul ederseniz göndermiş olduğumuz bu e-maile dönüş yapmanız yeterli olacaktır. Detayları daha sonra sizinle ayrıntılı bir şekilde konuşabiliriz.

Zaman ayırdığınız için teşekkür ederiz. yapım şirketi

Tablo 1. Oturum Planı

\begin{tabular}{|c|c|c|c|c|}
\hline Durumlar/Anlar & Teknikler & Yönerge & Roller & Araçlar/Gereçler \\
\hline $\begin{array}{l}\text { 1.Müdürün } \\
\text { öğretmeni çağırmas1 }\end{array}$ & Rol kartı & $\begin{array}{l}\text { Hazır olduğunuzda } \\
\text { başlayın. }\end{array}$ & $\begin{array}{l}\text { Müdür, } \\
\text { öğretmen }\end{array}$ & $\begin{array}{l}\text { Rol kartlarının } \\
\text { yazılı olduğu } \\
\text { kağıtlar }\end{array}$ \\
\hline $\begin{array}{l}\text { 2.Projenin kabul } \\
\text { edilip edilmemesi }\end{array}$ & $\begin{array}{l}\text { küçük grupla } \\
\text { doğaçlama, rol } \\
\text { koridoru }\end{array}$ & $\begin{array}{l}\text { Okul öğretmenleriyle ve } \\
\text { sınıf annesiyle durumu } \\
\text { değerlendirme, } \\
\text { Sinıf annesi gösterişe } \\
\text { meraklı }\end{array}$ & $\begin{array}{l}\text { Okul } \\
\text { öğretmenleri, } \\
\text { sinıf annesi, } \\
\text { öğretmenin eşi, } \\
\text { zümre } \\
\text { öğretmenleri }\end{array}$ & \\
\hline 3.Projenin kabulü & $\begin{array}{l}\begin{array}{l}\text { Öğretmenin role } \\
\text { girmesi }\end{array} \\
\text { Büyük grup } \\
\text { doğaçlama }\end{array}$ & $\begin{array}{l}\text { Müdür teklifi kabul } \\
\text { ettiğini söylüyor. Bu teklifi } \\
\text { kabul etme sebebini de } \\
\text { devletten çok az ödenek } \\
\text { aldıklarını, okulun bir } \\
\text { çok eksiğinin olduğunu } \\
\text { ve bunların okula şirket } \\
\text { tarafından bağışlanacak } \\
\text { parayla yapabileceği olarak } \\
\text { açılıyor. }\end{array}$ & $\begin{array}{l}\text { Müdür, } \\
\text { öğretmenler }\end{array}$ & dosyalar \\
\hline $\begin{array}{l}\text { 4. Medya yapım } \\
\text { şirketlerinin yapmış } \\
\text { oldukları dizilerin } \\
\text { incelenmesi }\end{array}$ & Toplantı & $\begin{array}{l}\text { Dizilerin konularını analiz } \\
\text { etme ve çocuklar için } \\
\text { uygun olanı belirleme }\end{array}$ & $\begin{array}{l}\text { Öğretmen, } \\
\text { müdür, }\end{array}$ & Kağıtlar, kalemler \\
\hline 5.İş bölümü-hazırlık & $\begin{array}{l}\text { Toplant1, telefon } \\
\text { görüşmesi, } \\
\text { Rol içinde } \\
\text { yazma }\end{array}$ & Adımları belirleme & $\begin{array}{l}\text { Öğretmen, veli, } \\
\text { müdür, medya } \\
\text { yapım şirketi } \\
\text { çalışanları }\end{array}$ & Kağıtlar, kalemler \\
\hline
\end{tabular}




\section{İKİNCI OTURUM}

Tarih: 17.03.2016

Konu: Görsel ve İşitsel Medyanın (Televizyon-Diziler) Etkisinin İncelenmesi

Süre: 3 saat

Üst Kazanım/lar:

Medya okuryazarlığı kavramı içerisinde yer alan ögelerin neler olduğunu ifade eder.

$\mathrm{Bu}$ ögeleri analiz edip değerlendirir.

$\mathrm{Bu}$ ögelere kendi hayatında nasıl yer vermesi gerektiğinin farkına varıp ve uygular.

\section{Tablo 3. Oturum Planı}

\begin{tabular}{|c|c|c|c|c|}
\hline Durumlar/Anlar & Teknikler & Yönerge & Roller & $\begin{array}{l}\text { Araçlar/ } \\
\text { Gereçler }\end{array}$ \\
\hline 6.Dizinin seçimi & $\begin{array}{l}\text { Toplantı, ikili } \\
\text { doğaçlama (rol } \\
\text { kartı),rol koridoru }\end{array}$ & $\begin{array}{l}\text { Gerekçelerinizi } \\
\text { sunun. }\end{array}$ & $\begin{array}{l}\text { Öğretmen, veli, } \\
\text { müdür, medya yapım } \\
\text { şirketi çalışanları }\end{array}$ & \\
\hline $\begin{array}{l}\text { 7.Gösterinin } \\
\text { hazırlanması }\end{array}$ & $\begin{array}{l}\text { Toplantı, ikili } \\
\text { doğaçlama, } \\
\text { Küçük grup } \\
\text { doğaçlama, }\end{array}$ & $\begin{array}{l}\text { Kostüm, mekan ve } \\
\text { rollerin belirlenip } \\
\text { gösterinin prova } \\
\text { edilmesi }\end{array}$ & $\begin{array}{l}\text { Öğretmen, veli, } \\
\text { müdür, çocuklar }\end{array}$ & \\
\hline 8.Gösteri anı & $\begin{array}{l}\text { Büyük grup } \\
\text { doğaçlama, ikili } \\
\text { doğaçlama }\end{array}$ & $\begin{array}{l}\text { Gösteriyi } \\
\text { canlandırın. }\end{array}$ & $\begin{array}{l}\text { Veli, öğretmenler, ilçe } \\
\text { milli eğitim müdürü, il } \\
\text { milli eğitim müdürü, } \\
\text { çocuklar }\end{array}$ & \\
\hline 9. Velilerin tepkisi & $\begin{array}{l}\text { Küçük grup } \\
\text { doğaçlama, } \\
\text { İkili doğaçlama, } \\
\text { Büyük grup } \\
\text { doğaçlama }\end{array}$ & $\begin{array}{l}\text { Velilerden birisi } \\
\text { "aaa olamaz benim } \\
\text { çocuğuma bu rolümü } \\
\text { verdiniz inanamıor" } \\
\text { demesiyle başlayan } \\
\text { süreci canlandırınız. }\end{array}$ & $\begin{array}{l}\text { Veli, öğretmenler, ilçe } \\
\text { milli eğitim müdürü, il } \\
\text { milli eğitim müdürü, } \\
\text { çocuklar }\end{array}$ & \\
\hline 10.Çocukların Tepkisi & $\begin{array}{l}\text { Küçük grup } \\
\text { doğaçlama, } \\
\text { İkili doğaçlama, } \\
\text { Büyük grup } \\
\text { doğaçlama }\end{array}$ & $\begin{array}{l}\text { Heyecandan bir } \\
\text { çocuk ne söyleceğini } \\
\text { unutmuştur ve } \\
\text { keklemeye başlar bu } \\
\text { an ile başlayan süreci } \\
\text { canlandırınız. }\end{array}$ & $\begin{array}{l}\text { Veli, öğretmenler, ilçe } \\
\text { milli eğitim müdürü, il } \\
\text { milli eğitim müdürü, } \\
\text { çocuklar }\end{array}$ & \\
\hline $\begin{array}{l}\text { 11.Gazete } \\
\text { patronlarından birisi } \\
\text { sizin ve velilerinizin } \\
\text { izni olmadan bu } \\
\text { gösteriyi yayınlanmış. }\end{array}$ & $\begin{array}{l}\text { Donuk imge, } \\
\text { küçük grup } \\
\text { doğaçlama,rüya } \\
\text { tekniği }\end{array}$ & $\begin{array}{l}\text { Gazete haberini } \\
\text { gördüğünüz anı } \\
\text { canlandırma }\end{array}$ & Öğretmen, veli & \\
\hline
\end{tabular}

